\title{
Nontuberculous Mycobacterial Musculoskeletal Infection Cases from a Tertiary Referral Center, Colorado, USA
}

\author{
Noah Goldstein, ${ }^{1}$ J. Benjamin St. Clair, ${ }^{1}$ Shannon H. Kasperbauer, Charles L. Daley, Bennie Lindeque
}

\section{$\underset{\text { MDUCATION }}{\text { Medscape ACTIVITY }}$}

In support of improving patient care, this activity has been planned and implemented by Medscape, LLC and Emerging Infectious Diseases. Medscape, LLC is jointly accredited by the Accreditation Council for Continuing Medical Education (ACCME), the Accreditation Council for Pharmacy Education (ACPE), and the American Nurses Credentialing Center (ANCC), to provide continuing education for the healthcare team.

Medscape, LLC designates this Journal-based CME activity for a maximum of 1.00 AMA PRA Category 1 Credit(s) ${ }^{\mathrm{TM}}$. Physicians should claim only the credit commensurate with the extent of their participation in the activity.

Successful completion of this CME activity, which includes participation in the evaluation component, enables the participant to earn up to $1.0 \mathrm{MOC}$ points in the American Board of Internal Medicine's (ABIM) Maintenance of Certification (MOC) program. Participants will earn MOC points equivalent to the amount of CME credits claimed for the activity. It is the CME activity provider's responsibility to submit participant completion information to ACCME for the purpose of granting ABIM MOC credit.

All other clinicians completing this activity will be issued a certificate of participation. To participate in this journal CME activity: (1) review the learning objectives and author disclosures; (2) study the education content; (3) take the post-test with a $75 \%$ minimum passing score and complete the evaluation at http://www.medscape.org/journal/eid; and (4) view/print certificate. For CME questions, see page 1260 .

Release date: May 17, 2019; Expiration date: May 17, 2020

Learning Objectives

Upon completion of this activity, participants will be able to:

- Describe clinical characteristics of patients with nontuberculous mycobacterial (NTM) nonspinal musculoskeletal infections, according to a case series of 14 patients treated at University of Colorado Hospital (UCH) over a 6-year period

- Determine medical and surgical management of patients with NTM nonspinal musculoskeletal infections, based on a case series of 14 patients treated at $\mathrm{UCH}$ over a 6 -year period

- Explain microbiological and histopathological findings and treatment outcomes of patients with NTM nonspinal musculoskeletal infections, based on a case series of 14 patients treated at UCH over a 6 -year period

\section{CME Editor}

Dana C. Dolan, BS, Copyeditor, Emerging Infectious Diseases. Disclosure: Dana C. Dolan, BS, has disclosed no relevant financial relationships.

\section{CME Author}

Laurie Barclay, MD, freelance writer and reviewer, Medscape, LLC. Disclosure: Laurie Barclay, MD, has disclosed no relevant financial relationships.

\section{Authors}

Disclosures: Noah Goldstein, BS; J. Benjamin St Clair, MD, PhD; and Bennie Lindeque, MD, PhD, have disclosed no relevant financial relationships. Shannon H. Kasperbauer, MD, has disclosed the following relevant financial relationships: served as an advisor or consultant for Insmed Incorporated; served as a speaker or a member of a speakers bureau for Insmed Incorporated; received grants for clinical research from Insmed Incorporated. Charles L. Daley, MD, has disclosed the following relevant financial relationships: served as an advisor or consultant for Horizon Pharma; Insmed Incorporated; Johnson \& Johnson Pharmaceutical Research \& Development, L.L.C.; Paratek Pharmaceuticals; Spero Therapeutics; received grants for clinical research from Insmed Incorporated.

Author affiliations: University of Colorado, Aurora, Colorado, USA N. Goldstein, J.B. St. Clair, S.H. Kasperbauer, B. Lindeque); University of Chicago, Chicago, Illinois, USA (J.B. St. Clair); National Jewish Health, Denver, Colorado, USA

(S.H. Kasperbauer, C.L. Daley)

DOI: https://doi.org/10.3201/eid2506.181041

${ }^{1}$ These first authors contributed equally to this article.
Nontuberculous mycobacteria represent an uncommon but important cause of infection of the musculoskeletal system. Such infections require aggressive medical and surgical treatment, and cases are often complicated by delayed diagnosis. We retrospectively reviewed all 14 nonspinal cases of nontuberculous mycobacterial musculoskeletal infections treated over 6 years by orthopedic surgeons at a university-affiliated tertiary referral center. All patients 
required multiple antimicrobial agents along with aggressive surgical treatment; 13 of 14 patients ultimately achieved cure. Four patients required amputation to control the infection. Half these patients were immunosuppressed by medications or other medical illness when they sought care at the referral center. Six cases involved joint prostheses; all ultimately required hardware removal and placement of an antimicrobial spacer for eradication of infection. Our findings highlight the importance of vigilance for nontuberculous mycobacterial musculoskeletal infection, particularly in patients who are immunosuppressed or have a history of musculoskeletal surgery.

$\mathrm{N}$ ontuberculous mycobacteria (NTM) are opportunistic pathogens found in soil and water and are the sources of an increasing number of infections and illness $(1,2)$. Multiple recent studies have recognized this temporal trend of increasing annual prevalence of NTM disease; current prevalence is estimated at $2.6 \%-10 \%$ annually (1-4). NTM cause a broad range of clinical manifestations, depending on the immune competency of the host. Pulmonary disease is most common and is often seen in immunocompetent hosts. It is difficult to estimate the prevalence of extrapulmonary NTM infection in the United States because no system of national surveillance and reporting exists as for tuberculosis. Reported laboratory isolation data indicate that extrapulmonary disease may comprise up to one quarter of all NTM infections, although the best estimates are based on data that are 1-3 decades old. Data from the mid-1990s estimated the overall US incidence of NTM infection at $1.0 \%-1.8 \%$, with $\approx 5 \%$ of isolates reported to the Centers for Disease Control and Infection at that time being of extrapulmonary origin. A population-based record review in Oregon that used data gathered during 2005-2006 found $\approx 22 \%$ of isolates originating from nonpulmonary specimens. Data from North Carolina gathered during 2006-2010 showed $16 \%-23 \%$ of total isolates originating from extrapulmonary specimens (5-7). Skin and soft tissue infections represent most extrapulmonary NTM disease, whereas bone and joint disease is less common. With increasing immunosuppression, NTM is more likely to manifest as disseminated disease, possibly including bone and joint involvement.

Previous case reports and series of NTM musculoskeletal infections have focused on the demographics, diagnosis, and treatment of patients with these difficult-to-manage infections $(8-24)$. Patients were often immunocompetent persons who contracted an NTM disease after direct inoculation via traumatic skin puncture (25-28). In a series of 29 cases from South Korea, all patients required surgical intervention in addition to antimicrobial drugs; 3 patients failed to respond despite aggressive treatment, and an additional 4 were lost to follow-up. Of note, only 20 of the patients in this series received NTM-specific antimicrobial therapy; the remainder were treated with empirical antimicrobial therapy. A series of 28 cases of $M$. marinum musculoskeletal infections found that $93 \%$ of cases involved fingers or hands and $87 \%$ were related to aquatic exposure; two thirds progressed from cutaneous to invasive infection. Most cases were managed with multiple antimycobacterial agents in addition to surgery, and the series reported a $75 \%$ cure rate and $25 \%$ loss to follow-up. A study of 8 cases of prosthetic joint infection (PJI) caused by rapidly growing mycobacteria found that the median interval from prosthesis implantation to infection was 312 weeks and that all patients required either resection and explantation of infected prostheses or chronic suppressive antimicrobial therapy.

In these series, infections occurred throughout the musculoskeletal system but were particularly common in the hands and spine. Identification of NTM as the causative agent was often delayed due to the indolent course of the infection and lack of appropriate diagnostic testing. Once identified, the infections could be treated effectively with a combination of debridement and conventional antimycobacterial chemotherapy.

We reviewed all cases of nonspinal NTM musculoskeletal infection treated at the University of Colorado Hospital (UCH; Aurora, CO, USA) over a 6-year period by a multidisciplinary team of providers at $\mathrm{UCH}$ and National Jewish Health (NJH; Denver, CO, USA), a renowned center for mycobacterial research and treatment that receives referrals for difficult-to-treat NTM infections from across the United States. Our aim was to describe the clinical characteristics and treatment outcomes of patients with NTM musculoskeletal infections.

\section{Materials and Methods}

\section{Study Design}

We performed a retrospective study of patients with nonspinal NTM musculoskeletal infections treated at UCH during 2009-2015. The management of each case was directed by an orthopedic surgeon and infectious disease physicians at $\mathrm{UCH}$ and NJH. For patients with positive culture results at $\mathrm{UCH}$, mycobacterial speciation and susceptibility data were identified by ARUP Laboratories (https://www.aruplab.com) using DNA sequencing or matrix-assisted laser desorption/ionization time-of-flight mass spectrometry.

\section{Case Ascertainment}

We identified all cases of nonspinal NTM musculoskeletal infections treated by orthopedic surgeons at $\mathrm{UCH}$ during the study period using a registry of NTM musculoskeletal infections. We omitted spinal cases because they are handled by a different department at $\mathrm{UCH}$ and so were not 
part of the surgeons' personal registry. We reviewed the medical records of patients after approval from the Institutional Review Board.

\section{Data Collection}

We performed our review of the medical records using a standardized case report form. We collected demographic characteristics and data on concurrent conditions, laboratory values, surgical intervention, antimycobacterial chemotherapy, and outcomes.

\section{Literature Review}

We searched the Medline database to identify case reports and reviews of NTM musculoskeletal infections. We used both the PubMed and Ovid access tools.

\section{Results}

\section{Patient Characteristics}

Of the 14 patients in our series, 7 were receiving immunosuppressive medications at arrival, and 5 of those had chronic autoimmune disease. Twelve patients were referred from NJH. No predisposing host factor was identified for 6 patients. (Table 1).

\section{Clinical Presentation and Diagnosis}

The patients had a wide array of sites of infection when they sought care at UCH (5 knee, 2 hip, 1 thigh, 1 hand, 1 foot, 1 elbow, 3 with disseminated disease at multiple sites). The diagnosis at arrival was most commonly PJI $(\mathrm{n}=6)$; the next most common diagnoses included septic

\begin{tabular}{|c|c|c|c|c|c|c|c|}
\hline $\begin{array}{l}\text { Patient } \\
\text { no. }\end{array}$ & $\begin{array}{l}\text { Age, } \\
\text { y/sex }\end{array}$ & $\begin{array}{l}\text { Immunocompromising } \\
\text { conditions }\end{array}$ & $\begin{array}{l}\text { Inciting or } \\
\text { predisposing } \\
\text { factor(s) }\end{array}$ & $\begin{array}{l}\text { Time to } \\
\text { symptom } \\
\text { onset, mo }\end{array}$ & $\begin{array}{l}\text { Reason care } \\
\text { sought }\end{array}$ & $\begin{array}{l}\text { Time from } \\
\text { symptom } \\
\text { onset to } \\
\text { diagnosis, mo }\end{array}$ & $\begin{array}{l}\text { Diagnostic procedure, } \\
\text { source of } \\
\text { microbiologic diagnosis }\end{array}$ \\
\hline 1 & $55 / \mathrm{M}$ & $\begin{array}{l}\text { History of lymphoma, } \\
\text { pseudogout, } \\
\text { oral steroid use }\end{array}$ & $\begin{array}{l}\text { Steroid } \\
\text { injection, } \\
\text { left ankle }\end{array}$ & UNK & $\begin{array}{l}\text { Osteomyelitis, } \\
\text { septic arthritis }\end{array}$ & 12 & $\begin{array}{l}\text { Tissue sample from } \\
\text { ankle debridement }\end{array}$ \\
\hline 2 & $53 / \mathrm{F}$ & None & Pedicure & 0 & $\begin{array}{l}\text { Synovitis, } \\
\text { osteomyelitis, } \\
\text { cellulitis }\end{array}$ & 4 & $\begin{array}{l}\text { UNK; diagnosis at } \\
\text { another hospital }\end{array}$ \\
\hline 3 & $48 / F$ & None & Second THA & UNK & PJI & UNK & $\begin{array}{c}\text { Thigh fluid sampled } \\
\text { during I\&D }\end{array}$ \\
\hline 4 & $45 / \mathrm{M}$ & None & AKA & 1 & $\begin{array}{l}\text { Draining wound } \\
\text { at stump }\end{array}$ & 2 & $\begin{array}{l}\text { Sample of fluid draining } \\
\text { from AKA stump }\end{array}$ \\
\hline 5 & $64 / F$ & None & $\begin{array}{l}\text { Carpal tunnel } \\
\text { release }\end{array}$ & 0 & $\begin{array}{l}\text { Tenosynovitis, } \\
\text { septic arthritis }\end{array}$ & 8 & $\begin{array}{l}\text { Synovial fluid obtained } \\
\text { during excision of } \\
\text { synovitis }\end{array}$ \\
\hline 6 & $69 / F$ & Diabetes mellitus & THA & 6 & PJI & 9 & $\begin{array}{l}\text { Synovial biopsy } \\
\text { obtained during } \\
\text { explantation }\end{array}$ \\
\hline 7 & $23 / F$ & $\begin{array}{c}\text { Systemic lupus } \\
\text { erythematosus, oral } \\
\text { steroids, } \\
\text { hydroxyl-chloroquine, } \\
\text { mycophenolate mofetil }\end{array}$ & $\begin{array}{l}\text { Avascular } \\
\text { necrosis, ankle } \\
\text { fusion }\end{array}$ & 3 & $\begin{array}{l}\text { Septic arthritis, } \\
\text { osteomyelitis, skin } \\
\text { abscesses }\end{array}$ & 1 & $\begin{array}{l}\text { UNK; diagnosis at } \\
\text { another hospital }\end{array}$ \\
\hline 8 & $57 / F$ & $\begin{array}{l}\text { Polymyositis, oral } \\
\text { steroids, azathioprine, } \\
\text { rituximab,methotrexate }\end{array}$ & $\begin{array}{l}\text { ACL repair, } \\
\text { arthroscopy, } \\
\text { steroid injection }\end{array}$ & UNK & Septic arthritis & UNK & $\begin{array}{l}\text { Aspirate of left knee } \\
\text { and right hip }\end{array}$ \\
\hline 9 & $76 / \mathrm{M}$ & $\begin{array}{c}\text { Nonspecific } \\
\text { autoimmune disease, } \\
\text { oral steroids }\end{array}$ & $\begin{array}{c}\text { Calcium } \\
\text { pyrophosphate } \\
\text { deposition } \\
\text { disease, TKA }\end{array}$ & 0 & PJI & 2 & $\begin{array}{l}\text { UNK; diagnosis at } \\
\text { another hospital }\end{array}$ \\
\hline 10 & $58 / \mathrm{M}$ & None & $\begin{array}{c}\text { Trauma, steroid } \\
\text { injection }\end{array}$ & 12 & Septic arthritis & 19 & $\begin{array}{l}\text { UNK; diagnosis at } \\
\text { another hospital }\end{array}$ \\
\hline 11 & $77 / F$ & $\begin{array}{l}\text { Rheumatoid arthritis, } \\
\text { prednisone, } \\
\text { azathioprine }\end{array}$ & TKA & 300 & PJI & 12 & $\begin{array}{c}\text { Synovial biopsy } \\
\text { obtained during } \\
\text { placement of } \\
\text { antimicrobial spacer }\end{array}$ \\
\hline 12 & $83 / \mathrm{M}$ & $\begin{array}{l}\text { Malnutrition, } \\
\text { prednisone }\end{array}$ & TKA & 168 & PJI & 8 & $\begin{array}{c}\text { Tissue obtained during } \\
\text { TKA revision }\end{array}$ \\
\hline 13 & $49 / F$ & None & TKA (revision) & 14 & PJI & 2 & $\begin{array}{l}\text { UNK; diagnosis at } \\
\text { another hospital }\end{array}$ \\
\hline 14 & $24 / F$ & $\begin{array}{l}\text { Crohn's disease, } \\
\text { infliximab }\end{array}$ & Failed IV & 0 & Cellulitis, abscess & 7 & Skin biopsy \\
\hline
\end{tabular}


arthritis ( $\mathrm{n}=5)$, osteomyelitis $(\mathrm{n}=3)$, tendon sheath infection $(\mathrm{n}=2)$, skin abscess $(\mathrm{n}=2)$, cellulitis $(\mathrm{n}=2)$, and surgical-wound infection $(\mathrm{n}=1)$. Several patients had complex local infections with multiple concurrent tissue diagnoses; case-patients 1, 7, and 8 had disseminated disease at multiple sites. Each patient had undergone $\geq 1$ prior procedure at the site of infection, including 6 patients with infected prostheses, 4 with other surgical procedures, 2 with steroid injection, 1 with a failed intravenous (IV) placement, and 1 with a cosmetic pedicure. The median interval from symptom onset to diagnosis was 7.5 months (range 1-19 months).

Of 10 patients tested, the median erythrocyte sedimentation rate (ESR) was above the upper limit of normal (ULN) in 7 patients (70\%) at arrival (ULN $15 \mathrm{~mm} / \mathrm{h}$ in men, $20 \mathrm{~mm} / \mathrm{h}$ in women). C-reactive protein level was elevated in 4/14 patients (29\%) (ULN $10.0 \mathrm{mg} / \mathrm{L})$. Blood leukocyte count was elevated in 2/14 patients (14\%) (ULN $10.1 \times$ $10^{4}$ cells $/ \mu \mathrm{L}$ ). All 3 laboratory tests were within reference limits in 1 patient, and both C-reactive protein and leukocyte levels were within reference limits in an additional 2 patients without ESR data.

\section{PJIs}

Six patients arrived with PJI at the knee (4 patients) and hip (2 patients). The interval from prosthesis implantation to symptom onset ranged from the immediate aftermath of implantation to 25 years postimplantation; median duration was 6 months. Infected hardware was removed in all patients with PJI; the median period from symptom onset to explantation was 8.5 months (range $<3-16$ months). After explantation, 2-stage revision was undertaken, first with implantation of a temporary articulating prosthesis prepared with $1 \mathrm{~g}$ of antimicrobial-loaded polymethylmethacrylate bone cement, with drug selection based on sensitivity testing. This preparation, called an antimicrobial spacer, was subsequently replaced with a permanent prosthesis after several months without evidence of recurrent infection. Medicationloaded bone cement was also used for patients requiring intramedullary nailing. Patients with PJI were also treated with amikacin-containing calcium sulfate beads implanted within the surgical bed ( $1 \mathrm{~g}$ of amikacin per $10 \mathrm{cc}$ packet of calcium sulfate mixture). These antimicrobial beads were used at initial explantation or when the antimicrobial spacer was replaced with a permanent prosthesis at the discretion of the surgeon as needed to fill dead space from aggressive debridement or the infection itself. The precise amount of amikacin used is not always clearly reflected in the surgical record; however, in our series, use of up to $5 \mathrm{~g}$ of amikacin has been recorded. Amikacin is used for its activity against mycobacteria and its ability to integrate with the calcium sulfate material to form beads. Such amikacin-laden beads were also used in 2 other patients with extensive soft- tissue involvement. A seventh patient with septic arthritis of her native knee (case-patient 8) underwent a total knee arthroplasty that was insufficient to eradicate the infection and ultimately required subsequent 2 -stage revision.

\section{Surgical Treatment}

All patients required surgical treatment for control of infection, and all but 1 patient were ultimately cured by combined medical and surgical treatment. Seven patients had $\geq 1$ procedure at outside hospitals before seeking treatment at UCH. Case-patients 4 and 5 required only a single surgical procedure at UCH for control of infection. Case-patients 6 and 12 underwent planned 2-stage revision and required no further surgeries. The remaining 10 case-patients had initial procedures at $\mathrm{UCH}$ that were intended to definitively treat infection but proved unsuccessful. Surgical treatment at $\mathrm{UCH}$ consisted of aggressive debridement of infected bone and soft tissue, as well as explantation of any infected hardware with 2-stage revision of infected prostheses. Four patients with infections involving the knee also required placement of intramedullary nails coated with antibioticloaded cement (case-patients 9, 10, 11, and 13). The median interval from initial diagnostic or therapeutic procedure to definitive surgical treatment was 14 months (range 4-52 months) in the patients who required multiple procedures. One patient with disseminated M. abscessus (case-patient 1) required a debridement of the femur, partial claviculectomy, synovectomy of an ankle and a knee, and a fasciectomy. The patient with disseminated $M$. massiliense in the setting of chronic immunosuppressive therapy (casepatient 7) required $\geq 12$ procedures including multiple debridements and soft tissue excisions, removal of infected ankle fusion hardware, and osteotomy and arthrotomy of an infected elbow with extensive use of antimicrobial beads and bone cement. A patient with $M$. intracellulare infection disseminated to the left knee and right hip (case-patient 8) required multiple irrigations and debridements, total knee arthroplasty with antimicrobial spacer, and subsequent implantation of a tumor prosthesis. One patient with $M$. fortuitum infection (case-patient 5) had a debridement and eventually required amputation of her hand. One patient had cellulitis and abscess formation caused by M. marinum (case-patient 14) requiring a wide excision of the soft tissue around her elbow. One patient with a hip-prosthetic infection caused by $M$. abscessus (case-patient 3 ) required hemipelvectomy due to the progressive spread of the infection despite $>1$ year of intravenous therapy, prosthetic hip explantation, and multiple debridements (Table 2).

\section{Histopathology and Microbiology}

The species of NTM responsible for the musculoskeletal infection was known or identified in each patient. All patients had tissue specimens taken for culture during their 
Table 2. Surgical treatment of patients with nontuberculous mycobacterial musculoskeletal infections, Colorado, USA*

\begin{tabular}{|c|c|c|c|c|c|c|c|c|}
\hline \multirow[b]{2}{*}{$\begin{array}{l}\text { Patient } \\
\text { no. }\end{array}$} & \multirow[b]{2}{*}{ Site } & \multirow[b]{2}{*}{$\begin{array}{l}\text { Previous } \\
\text { surgeries }\end{array}$} & \multirow{2}{*}{$\begin{array}{c}\text { Symptom } \\
\text { onset to first } \\
\text { surgery, mo }\end{array}$} & \multicolumn{2}{|c|}{ Surgeries for control of infection at $\mathrm{UCH}$} & \multirow{2}{*}{$\begin{array}{c}\text { Time } \\
\text { between } \\
\text { surgeries, } \\
\text { mo }\end{array}$} & \multirow{2}{*}{$\begin{array}{c}\text { First visit to } \\
\text { definitive } \\
\text { procedure, } \\
\text { mo }\end{array}$} & \multirow{2}{*}{$\begin{array}{l}\text { Length of } \\
\text { follow-up, } \\
\text { mo }\end{array}$} \\
\hline & & & & First procedure(s) & $\begin{array}{c}\text { Definitive } \\
\text { procedure }\end{array}$ & & & \\
\hline 1 & $\begin{array}{l}\text { Multiple } \\
\text { joints } †\end{array}$ & $\begin{array}{l}\text { Multiple I\&Ds, } \\
\text { below-knee } \\
\text { amputation }\end{array}$ & UNK & $\begin{array}{c}\text { I\&D, excision of soft- } \\
\text { tissue masses, } \\
\text { debridement, } \\
\text { synovectomy, amikacin } \\
\text { bead implantation }\end{array}$ & $\begin{array}{l}\text { Wide excision of } \\
\text { right calf }\end{array}$ & 36 & 22 & 7 \\
\hline 2 & Left foot & $\begin{array}{c}\text { Debridement, } \\
\text { amputation } L \\
\text { 5th toe, nodule } \\
\text { excision } \\
\end{array}$ & 2 & $\begin{array}{l}\text { Debridement of dorsum } \\
\text { of left foot }\end{array}$ & $\begin{array}{l}\text { Excisional } \\
\text { debridement of } \\
\text { left foot }\end{array}$ & 17 & 14 & 60 \\
\hline 3 & $\begin{array}{l}\text { Left hip } \\
\text { (PJI) }\end{array}$ & UNK & UNK & $\begin{array}{c}\text { Debridement and } \\
\text { polyethylene exchange }\end{array}$ & $\begin{array}{c}\text { Hemi- } \\
\text { pelvectomy }\end{array}$ & 31 & 38 & 14 \\
\hline 4 & $\begin{array}{l}\text { Left } \\
\text { thigh }\end{array}$ & None & 18 & NA & $\begin{array}{l}\text { Above-knee } \\
\text { amputation } \\
\text { stump revision }\end{array}$ & NA & 14 & 1 \\
\hline 5 & $\begin{array}{l}\text { Right } \\
\text { hand }\end{array}$ & None & 9 & NA & $\begin{array}{l}\text { Amputation of } \\
\text { right hand and } \\
\text { forearm }\end{array}$ & NA & 3 & 37 \\
\hline 6 & $\begin{array}{l}\text { Right hip } \\
\text { (PJI) }\end{array}$ & None & 9 & $\begin{array}{c}\text { Resection arthroplasty, } \\
\text { tobramycin cement } \\
\text { spacer }\end{array}$ & Revision THA & 4 & 6 & 49 \\
\hline 7 & $\begin{array}{l}\text { Multiple } \\
\text { joints } \ddagger\end{array}$ & I\&D & 1 & $\begin{array}{l}\text { Hardware removal, I\&D, } \\
\text { amikacin bead } \\
\text { implantation, arthrotomy } \\
\text { and osteotomy with } \\
\text { amikacin cement, soft- } \\
\text { tissue excisions }\end{array}$ & $\begin{array}{l}\text { Excisional } \\
\text { debridement of } \\
\text { left forearm and } \\
\text { right foot with } \\
\text { amikacin bead } \\
\text { placement§ }\end{array}$ & 51 & 51 & 2 \\
\hline 8 & $\begin{array}{l}\text { Left } \\
\text { knee, } \\
\text { right hip }\end{array}$ & None & UNK & $\begin{array}{l}\text { I\&D, amikacin cement } \\
\text { spacer }\end{array}$ & $\begin{array}{l}\text { TKA with tumor } \\
\text { prosthesis, } \\
\text { gentamicin } \\
\text { cement, } \\
\text { amikacin beads }\end{array}$ & 7 & 8 & 48 \\
\hline 9 & $\begin{array}{l}\text { Left } \\
\text { knee } \\
(P J I)\end{array}$ & $\begin{array}{l}\text { Explant with } \\
\text { antimicrobial } \\
\text { spacer, I\&D }\end{array}$ & 4 & $\begin{array}{l}\text { I\&D, explantation, } \\
\text { tobramycin spacer, } \\
\text { intramedullary nail with } \\
\text { tobramycin cement, } \\
\text { revision of spacer }\end{array}$ & $\begin{array}{l}\text { Revision TKA } \\
\text { with tobramycin } \\
\text { cement and } \\
\text { amikacin beads }\end{array}$ & 20 & 12 & 20 \\
\hline 10 & $\begin{array}{l}\text { Left } \\
\text { knee }\end{array}$ & $\begin{array}{l}\text { Arthroscopic } \\
\text { meniscectomy, } \\
\text { synovial } \\
\text { biopsy, } \\
\text { aspirations, } \\
\text { arthroscopic } \\
\text { synovectomy } \\
\end{array}$ & 2 & $\begin{array}{l}\text { Radical synovectomy, } \\
\text { amikacin bead } \\
\text { implantation, resection } \\
\text { arthroplasty, knee- } \\
\text { spanning intramedullary } \\
\text { nail with tobramycin } \\
\text { cement }\end{array}$ & $\begin{array}{l}\text { TKA with tumor } \\
\text { prosthesis and } \\
\text { tobramycin } \\
\text { cement }\end{array}$ & 40 & 12 & 4 \\
\hline 11 & $\begin{array}{l}\text { Right } \\
\text { knee } \\
\text { (PJI) }\end{array}$ & None & 12 & $\begin{array}{l}\text { Explantation, amikacin } \\
\text { spacer, I\&D, } \\
\text { intramedullary nail with } \\
\text { amikacin cement }\end{array}$ & $\begin{array}{l}\text { Revision TKA } \\
\text { with gentamicin } \\
\text { cement and } \\
\text { amikacin beads }\end{array}$ & 7 & 11 & 17 \\
\hline 12 & $\begin{array}{l}\text { Left } \\
\text { knee } \\
(P J I)\end{array}$ & $\begin{array}{c}\text { I\&D, } \\
\text { polyethylene } \\
\text { exchange }\end{array}$ & 0 & $\begin{array}{l}\text { Explantation, gentamicin } \\
\text { cement spacer }\end{array}$ & $\begin{array}{l}\text { Revision TKA } \\
\text { with tobramycin } \\
\text { cement and } \\
\text { amikacin beads }\end{array}$ & 12 & 5 & 20 \\
\hline 13 & $\begin{array}{l}\text { Right } \\
\text { knee } \\
\text { (PJI) }\end{array}$ & $\begin{array}{l}\text { Explant, I\&D, } \\
\text { antimicrobial } \\
\text { spacers }\end{array}$ & 3 & $\begin{array}{l}\text { Revision TKA, I\&D, } \\
\text { intramedullary nail with } \\
\text { amikacin cement }\end{array}$ & $\begin{array}{c}\text { Revision TKA } \\
\text { with amikacin } \\
\text { cement and } \\
\text { amikacin beads }\end{array}$ & 14 & 6 & 1 \\
\hline 14 & $\begin{array}{l}\text { Right } \\
\text { elbow }\end{array}$ & None & 8 & $\begin{array}{c}\text { Wide excision of right } \\
\text { forearm, nodule excision }\end{array}$ & $\begin{array}{l}\text { Wide excision of } \\
\text { right forearm }\end{array}$ & 4 & 10 & 47 \\
\hline
\end{tabular}

*I\&D, irrigation and debridement; NA, not applicable; PJI, prosthetic joint infection, THA, total hip arthroplasty; TKA, total knee arthroplasty; UNK, unknown.

†Infection was present in patient's left thigh and knee, and right talus, ankle joint, and subtalar joint.

fInfection was present in patient's left elbow, buttock, forearm, calf, right ankle and thigh, and both feet.

$\S B$ cause this patient is in treatment for chronic disseminated infection, definitive procedure is defined as the most recent surgical procedure. 
procedure(s) at UCH. Eight patients had microbiologic diagnoses of NTM infection before transfer to $\mathrm{UCH}$, and 6 of these patients were culture-negative at the time of surgery at $\mathrm{UCH}$ (case-patients 1, 2, 4, 8, 9, and 13). Antimicrobial therapy was initiated at outside hospitals in 6 of the 8 patients who came to UCH with established microbiologic diagnoses; the other 2 patients were referred directly to infectious diseases specialists at $\mathrm{UCH}, \mathrm{NJH}$, or both for treatment.

Seven patients were infected with a rapidly growing mycobacterial species, whereas the remaining 7 were infected with slowly growing species (Table 1). Ten patients had intraoperative biopsy specimens demonstrating granuloma formation, but only 2 of these had evidence of acid-fast bacilli on direct microscopy. Eight of 14 patients had intraoperative cultures that grew NTM, with speciation consistent with prior data when available. All patients had visual evidence of infection at the time of operation.
One patient who had M. marinum worked at a pet store that sold fish and aquariums and frequently submerged her hands and arms in the water, and her infection originated at a failed IV site. In the 5 patients with $M$. avium complex, 3 had speciation available that identified M. intracellulare.

\section{Antimicrobial Treatment}

All patients were treated with combination antimycobacterial chemotherapy (Table 3) determined on the basis of antimicrobial drug sensitivities (Appendix Table, https:// wwwnc.cdc.gov/EID/article/25/6/18-1041-App1.xlsx) and recommendations from $\mathrm{NJH}$. Thirteen of 14 patients were receiving antimycobacterial therapy at the time of surgery based on previous culture and drug susceptibility test results. Antimicrobial therapy was not administered around the time of surgery for case-patient 7 because of adverse effects from these medications.

Table 3. Microbiology and antimicrobial treatment of patients with nontuberculous mycobacterial musculoskeletal infections, Colorado, USA $^{*}$

\begin{tabular}{|c|c|c|c|c|c|c|}
\hline $\begin{array}{l}\text { Patient } \\
\text { no. }\end{array}$ & Species & $\begin{array}{c}\text { Oral therapy (duration, } \\
\text { mo) }\end{array}$ & $\begin{array}{l}\text { Intravenous therapy } \\
\text { (duration, mo) }\end{array}$ & $\begin{array}{l}\text { Total duration } \\
\text { of therapy, mo }\end{array}$ & $\begin{array}{c}\text { Time from last surgery to } \\
\text { cessation of antimicrobial } \\
\text { therapy, mo }\end{array}$ & Outcome \\
\hline 1 & M. abscessus & Azithromycin (24) & $\begin{array}{c}\text { Tigecycline + } \\
\text { amikacin }+ \\
\text { imipenem (24) }\end{array}$ & 24 & 0 & Cured \\
\hline 2 & M. abscessus & $\begin{array}{l}\text { Azithromycin }+ \text { linezolid } \\
(6)\end{array}$ & $\begin{array}{c}\text { Amikacin + } \\
\text { imipenem (6) }\end{array}$ & 6 & 0 & Cured \\
\hline 3 & M. abscessus & $\begin{array}{l}\text { Azithromycin + } \\
\text { clofazimine }(20)\end{array}$ & $\begin{array}{c}\text { Imipenem + } \\
\text { amikacin (15) }\end{array}$ & 20 & 0 & Cured \\
\hline 4 & M. abscessus & $\begin{array}{l}\text { Azithromycin + } \\
\text { clofazimine (14) }\end{array}$ & $\begin{array}{c}\text { Cefoxitin + amikacin } \\
\text { (8) }\end{array}$ & 14 & 0 & Cured \\
\hline 5 & M. fortuitum & Moxifloxacin (2) & Imipenem (2) & 2 & 1 & Cured \\
\hline 6 & M. fortuitum & $\begin{array}{c}\text { Doxycycline + } \\
\text { ciprofloxacin + } \\
\text { trimethoprim/ } \\
\text { sulfamethoxazole (5) }\end{array}$ & Amikacin (3) & 5 & 3 & Cured \\
\hline 7 & M. massiliense & Azithromycin, linezolid (4) & $\begin{array}{l}\text { Cefoxitin, tigecycline, } \\
\text { linezolid, amikacin, } \\
\text { azithromycin (4) } \\
\end{array}$ & $4 \dagger$ & NA & $\begin{array}{l}\text { Treatment } \\
\text { failure }\end{array}$ \\
\hline 8 & M. intracellulare & $\begin{array}{c}\text { Azithromycin + } \\
\text { ethambutol + rifabutin } \\
(14)\end{array}$ & Amikacin (8) & 14 & 1 & Cured \\
\hline 9 & $\begin{array}{l}\text { MAC, speciation } \\
\text { unavailable }\end{array}$ & $\begin{array}{c}\text { Azithromycin + } \\
\text { clofazimine + ethambutol } \\
+ \text { rifampin (39) }\end{array}$ & Amikacin (2) & 39 & 11 & Cured \\
\hline 10 & M. intracellulare & $\begin{array}{c}\text { Azithromycin + rifampin }+ \\
\text { clofazimine }+ \text { ethambutol } \\
(27)\end{array}$ & Amikacin (5) & 27 & 7 & Cured \\
\hline 11 & M. intracellulare & $\begin{array}{l}\text { Azithromycin + } \\
\text { moxifloxacin + } \\
\text { ethambutol (9) }\end{array}$ & None & 9 & 5 & Cured \\
\hline 12 & $\begin{array}{c}\text { MAC, speciation } \\
\text { unavailable }\end{array}$ & $\begin{array}{c}\text { Azithromycin + } \\
\text { ethambutol + rifampin (7) }\end{array}$ & None & 7 & 3 & Cured \\
\hline 13 & M. gordonae & $\begin{array}{c}\text { Azithromycin }+ \\
\text { trimethoprim/ } \\
\text { sulfamethoxazole }+ \\
\text { ethambutol }(16)\end{array}$ & Amikacin (2) & 16 & 2 & Cured \\
\hline 14 & M. marinum & $\begin{array}{l}\text { Azithromycin + } \\
\text { ciprofloxacin (14) }\end{array}$ & Imipenem (10) & 14 & 10 & Cured \\
\hline
\end{tabular}

${ }^{*}$ All bacteria are Mycobacterium spp. MAC, Mycobacterium avium complex.

†Patient elected to discontinue antimicrobial treatment after experiencing intolerable side effects from multiple medications, despite ongoing disseminated infection. 
Amikacin-related toxicity occurred in 3 patients. Ototoxicity occurred in 2 patients: case-patient 1 reported hearing loss after 9 months of parenteral amikacin and within 1 month of implantation of amikacin beads, and case-patient 6 experienced tinnitus after 3 months of parenteral amikacin. Kidney injury occurred in case-patient 7 after 3 months of parenteral amikacin and 1 month after implantation of amikacin beads (creatinine level increased from 0.71 to $2.37 \mathrm{mg} / \mathrm{dL}$ ). Tigecycline was also discontinued in case-patient 7 due to intractable nausea and vomiting within 2 days of initiation, and cefoxitin was discontinued due to fever within 3 days of treatment. Clofazimine also caused intractable nausea and vomiting upon initiation in this patient and was discontinued after 1 month. Apart from case-patient 1, who experienced permanent hearing loss, toxicity resolved with discontinuation of medications. Two patients with M. avium complex infection did not receive amikacin due to history of $C$. difficile infection (case-patients 10 and 11).

The median duration of antimicrobial chemotherapy was 14 months (range 2-39 months). Among the 7 patients with rapidly growing NTM, the median duration was 6 months. The median duration was longer in patients with slow-growing NTM, at 14 months. Twelve patients received injectable antimicrobial drugs as part of their treatment regimen, whereas 2 patients had oral therapy alone. The median duration of therapy with injectable agents was 5 months; rapidly growing strains were treated for a median of 6 months and slow-growing strains for a median of 5 months. The median duration of antimicrobial drug therapy after definitive surgery was 2 months. Patients infected with slow-growing NTM received a more protracted course of postoperative antimicrobial therapy, with a median duration of 5 months, compared with $<1$ month in patients infected with rapidly growing strains.

\section{Outcomes}

During the follow-up period after surgical intervention (median duration 20 months, range 1-60 months), 13/14 patients did not develop clinical or microbiological relapse and were cured. One (case-patient 7) had clinical and microbiological relapse and was deemed to have failed treatment; the first relapse occurred 2 months after the first surgery to control the infection. The relapse, a disseminated infection distant from the original surgical site, was a likely result of the patient receiving multiple immunosuppressive medications to control systemic lupus erythematosus. She required 12 surgical procedures within the first year and subsequently required $\approx 1$ procedure/year for control of chronic disseminated infection over the next 3 years, primarily in the form of debridement and excision of soft tissue mass. Of note, this patient chose to forgo antimicrobial therapy after the first 4 months of treatment because of intolerable side effects from multiple medications. Two instances of microbiologic relapse were documented for this patient.

\section{Discussion}

We present a series of cases of NTM musculoskeletal infections requiring surgical intervention and antimycobacterial chemotherapy that were managed at $\mathrm{UCH}$ and $\mathrm{NJH}$ over a 6-year period. NTM musculoskeletal infections have been reported in the literature sporadically due to their rare occurrence; 2 previous case series documented 29 cases over 13 years in South Korea (27) and 8 cases of PJI by NTM over 4 decades at the Mayo Clinic in the United States (26). In a 6-year period, we have identified 14 case-patients treated at our institutions with unique characteristics, in comparison to previous studies (25-28). Specifically, the cases we report indicate the importance of a low threshold for suspicion and testing for NTM in any patient who has an unidentified musculoskeletal infection, particularly with evidence of granuloma formation on pathology. Furthermore, for all of our case-patients, NTM infections developed at the site of a prior procedure (prosthetic joint or other intervention), raising the concept of early culture for mycobacteria in conjunction with or after negative results from conventional bacterial culture.

One of the most notable findings from the 3 previous case series studying NTM musculoskeletal infections was that, in all studies, the overwhelming majority of the patients were immunocompetent (26-28). In contrast, half the patients in our study were immunosuppressed as a result of either an underlying medical condition or a medication used to treat rheumatologic disease. While this may be a manifestation of the relationship between $\mathrm{UCH}$ and $\mathrm{NJH}$, our report highlights the importance of hypervigilance for possible NTM in immunocompromised patients with musculoskeletal infections. The most severely immunocompromised patients in our series (case-patients 1,7 , and 8 ) had disseminated infection. Immunocompromised patients with a history of musculoskeletal surgery should receive a mycobacterial workup as a component of their care.

Another crucial aspect of our case series is the observation that $10 / 14$ cases occurred at the site of a previous musculoskeletal surgery and 6 of these cases involved a joint prosthesis. Moreover, all 14 cases were preceded by an invasive procedure at the initial site of infection. In all but 3 of our surgery-associated cases, the onset of symptoms occurred $\geq 3$ months after the preceding surgical procedure, suggesting hematogenous spread, possibly due to transient mycobacteremia, with seeding of surgically altered tissue as the likely mechanism of inoculation. This mechanism is particularly likely in case-patients $1,7,8,11$, and 12 , which comprise 3 cases of disseminated infection in severely immunocompromised patients and 2 late prosthetic joint 
infections with more than a decade between initial prosthetic joint surgery and eventual infection. The previous report from South Korea noted a minority of periprosthetic infections, but most cases were related to trauma or iatrogenic injections rather than surgery (27).

The report from the Mayo Clinic focused on PJIs but noted only 8 cases over 4 decades (26). A recent series of 6 cases of chronic trauma- or intervention-related joint infection not responding to empiric therapy reported no cases of periprosthetic NTM infection (29). Our relatively rapid accumulation of surgery-related cases over a 6 -year period is due to the relationship between UHC and NJH and NJH's high volume of NTM cases; we cannot generalize this trend to the general US population, given the unique referral characteristics of our patient population. It is possible that improvements in detection and identification of NTM infections may contribute to this increased case volume, as has been suggested to explain the increasing incidence and prevalence of pulmonary NTM (30). Regardless, infections in our study were more likely to occur at the site of a previous orthopedic surgery and in $\geq 4$ cases led to severe complications requiring partial or full amputation, with 1 patient requiring hemipelvectomy. Three of these patients were infected with $M$. abscessus and 1 with $M$. fortuitum. M. abscessus is highly drug resistant and therefore responds poorly to antimicrobial therapy. It is difficult to ascertain if these amputations could have been avoided with earlier diagnosis and aggressive surgical therapy. In several cases, patients with long delays in diagnosis ultimately required amputation; almost one third of patients in our series required amputation.

Given the importance in identifying NTM musculoskeletal infections in the immunocompromised or those with prior surgery, it is unfortunate that our data did not identify more substantial diagnostic criteria based upon inflammatory markers. Whereas the ESR in our patients was usually elevated, the C-reactive protein and leukocyte counts were typically normal. The patient who failed treatment had one of the highest ESRs in our patient group, nearly double the median value of 38 at intake, perhaps because of her chronic autoimmune condition.

All patients had positive mycobacterial cultures at time of initial diagnosis. Thirteen of 14 patients were receiving mycobacterial therapy at the time of surgery at our institution and only half of them were persistently positive for mycobacterial growth despite ongoing symptoms and intraoperative observation of sinus tract formation and suppuration. We are familiar with this phenomenon, and therefore do not require a positive culture to define failure of therapy. If a patient has ongoing signs of infection while receiving effective antimicrobial drugs (based on drug sensitivity testing), then they need more aggressive resection of infected tissue. The 3 patients with PJI and rapidly growing NTM infection all required prolonged courses of IV and oral antimicrobial therapy. One of the 3 patients with $M$. avium complex-related PJI also required 2 months of concomitant IV amikacin. All patients with PJIs required explantation of the infected hardware followed by antimicrobial spacer placement for $\geq 3$ months in addition to ongoing postoperative oral or intravenous antimicrobial therapy to achieve a successful outcome. In $\geq 5$ cases, microbiologic diagnosis of mycobacterial infection was only confirmed during the initial surgical intervention, and in each of these cases, prior or subsequent surgeries were required for ultimate control of infection. Ultimately, the fact that $10 / 14$ cases required multiple surgeries for control of infection with long intervals from onset of symptoms and initial seeking of care to identification of the infectious agent and finally definitive surgical treatment underscores the need for early identification and aggressive treatment of NTM infection.

\section{About the Author}

Dr. Goldstein is a graduate of the University of Colorado School of Medicine, Aurora, CO. He will begin his residency in psychiatry at the University of North Carolina in July 2019.

\section{References}

1. Prevots DR, Shaw PA, Strickland D, Jackson LA, Raebel MA, Blosky MA, et al. Nontuberculous mycobacterial lung disease prevalence at four integrated health care delivery systems. Am J Respir Crit Care Med. 2010;182:970-6. http://dx.doi.org/10.1164/ rccm.201002-03100C

2. Adjemian J, Olivier KN, Seitz AE, Holland SM, Prevots DR. Prevalence of nontuberculous mycobacterial lung disease in U.S. Medicare beneficiaries. Am J Respir Crit Care Med. 2012;185: 881-6. http://dx.doi.org/10.1164/rccm.201111-2016OC

3. Al-Houqani M, Jamieson F, Mehta M, Chedore P, May K, Marras TK. Aging, COPD, and other risk factors do not explain the increased prevalence of pulmonary Mycobacterium avium complex in Ontario. Chest. 2012;141:190-7. http://dx.doi.org/10.1378/ chest.11-0089

4. Spaulding AB, Lai YL, Zelazny AM, Olivier KN, Kadri SS, Prevots DR, et al. Geographic distribution of nontuberculous mycobacterial species identified among clinical isolates in the United States, 2009-2013. Ann Am Thorac Soc. 2017;14:1655-61. http://dx.doi.org/10.1513/AnnalsATS.201611-860OC

5. Griffith DE, Aksamit T, Brown-Elliott BA, Catanzaro A, Daley C, Gordin F, et al.; ATS Mycobacterial Diseases Subcommittee; American Thoracic Society; Infectious Disease Society of America. An official ATS/IDSA statement: diagnosis, treatment, and prevention of nontuberculous mycobacterial diseases. Am J Respir Crit Care Med. 2007;175:367-416. http://dx.doi.org/10.1164/ rccm.200604-571ST

6. Smith GS, Ghio AJ, Stout JE, Messier KP, Hudgens EE, Murphy MS, et al. Epidemiology of nontuberculous mycobacteria isolations among central North Carolina residents, 2006-2010. J Infect. 2016;72:678-86. http://dx.doi.org/10.1016/j.jinf.2016.03.008

7. Cassidy PM, Hedberg K, Saulson A, McNelly E, Winthrop KL. Nontuberculous mycobacterial disease prevalence and risk factors: a changing epidemiology. Clin Infect Dis. 2009;49:e124-9. http://dx.doi.org/10.1086/648443 
8. Booth JE, Jacobson JA, Kurrus TA, Edwards TW. Infection of prosthetic arthroplasty by Mycobacterium fortuitum. Two case reports. J Bone Joint Surg Am. 1979;61:300-2. http://dx.doi.org/ 10.2106/00004623-197961020-00029

9. Horadam VW, Smilack JD, Smith EC. Mycobacterium fortuitum infection after total hip replacement. South Med J. 1982;75:244-6. http://dx.doi.org/10.1097/00007611-198202000-00036

10. Heathcock R, Dave J, Yates MD. Mycobacterium chelonae hip infection. J Infect. 1994;28:104-5. http://dx.doi.org/10.1016/ S0163-4453(94)94533-0

11. Pring M, Eckhoff DG. Mycobacterium chelonae infection following a total knee arthroplasty. J Arthroplasty. 1996;11:115-6. http://dx.doi.org/10.1016/S0883-5403(96)80170-7

12. Luque AE, Kaminski D, Reichman R, Hardy D. Mycobacterium szulgai osteomyelitis in an AIDS patient. Scand J Infect Dis. 1998;30:88-91. http://dx.doi.org/10.1080/003655498750002376

13. Breda L, de Michele G, Nozzi M, De Sanctis S, Di Marzio D, Chiarelli F. Non-tuberculous mycobacterial osteomyelitis: an unusual cause of hip pain in immunocompetent children. Rheumatol Int. 2009;29:1487-9. http://dx.doi.org/10.1007/ s00296-009-0844-4

14. Wang S-X, Yang C-J, Chen Y-C, Lay C-J, Tsai C-C. Septic arthritis caused by Mycobacterium fortuitum and Mycobacterium abscessus in a prosthetic knee joint: case report and review of literature. Intern Med. 2011;50:2227-32. http://dx.doi.org/10.2169/ internalmedicine.50.5610

15. Garcia DC, Sandoval-Sus J, Razzaq K, Young L. Vertebral osteomyelitis caused by Mycobacterium abscessus. BMJ Case Rep. 2013;2013:cr2013009597. http://dx.doi.org/10.1136/ bcr-2013-009597

16. Suy F, Carricajo A, Grattard F, Cazorla C, Denis C, Girardin P, et al. Infection due to Mycobacterium thermoresistibile: a case associated with an orthopedic device. J Clin Microbiol. 2013;51:3154-6. http://dx.doi.org/10.1128/JCM.00925-13

17. Bakhsh WR, Mesfin A. Mycobacterium kansasii infection of the spine in a patient with sarcoidosis: a case report and literature review. J Surg Orthop Adv. 2014;23:162-5. http://dx.doi.org/ 10.3113/JSOA.2014.0162

18. Hazara AM, Edey M, Roy A, Bhandari S. Rapidly growing non-tuberculous mycobacterial infection in a renal transplant patient after alemtuzumab induction. Transpl Infect Dis. 2014;16:847-52. http://dx.doi.org/10.1111/tid.12269

19. Kato S, Murakami H, Demura S, Yoshioka K, Hayashi H, Yokogawa N, et al. Vertebral osteomyelitis caused by Mycobacterium abscessus surgically treated using antibacterial iodine-supported instrumentation. Case Rep Orthop. 2014;2014:197061. http://dx.doi.org/10.1155/2014/197061

20. Nguyen HH, Fadul N, Ashraf MS, Siraj DS. Osteomyelitis infection of Mycobacterium marinum: a case report and literature review. Case Rep Infect Dis. 2015;2015:905920. http://dx.doi.org/ $10.1155 / 2015 / 905920$

21. Sharma VK, Pai G, Deswarte C, Lodha R, Singh S, Kang LW, et al. Disseminated Mycobacterium avium complex infection in a child with partial dominant interferon gamma receptor 1 deficiency in India. J Clin Immunol. 2015;35:459-62. http://dx.doi.org/10.1007/ s10875-015-0173-1

22. Silva JT, López-Medrano F, Fernández-Ruiz M, San-Juan R, Ruiz-Cano MJ, Delgado JF, et al. Mycobacterium abscessus pulmonary infection complicated with vertebral osteomyelitis in a heart transplant recipient: case report and literature review. Transpl Infect Dis. 2015;17:418-23. http://dx.doi.org/10.1111/tid.12381

23. Wood BR, Buitrago MO, Patel S, Hachey DH, Haneuse S, Harrington RD. Mycobacterium avium complex osteomyelitis in persons with human immunodeficiency virus: case series and literature review. Open Forum Infect Dis. 2015;2:ofv090. http://dx.doi.org/10.1093/ofid/ofv090

24. Kuntz M, Seidl M, Henneke P. Osteomyelitis because of Mycobacterium xenopi in an immunocompetent child. Pediatr Infect Dis J. 2016;35:110-3.

25. Marchevsky AM, Damsker B, Green S, Tepper S. The clinicopathological spectrum of non-tuberculous mycobacterial osteoarticular infections. J Bone Joint Surg Am. 1985;67:925-9. http://dx.doi.org/10.2106/00004623-198567060-00015

26. Eid AJ, Berbari EF, Sia IG, Wengenack NL, Osmon DR, Razonable RR. Prosthetic joint infection due to rapidly growing mycobacteria: report of 8 cases and review of the literature. Clin Infect Dis. 2007;45:687-94. http://dx.doi.org/10.1086/520982

27. Park JW, Kim YS, Yoon JO, Kim JS, Chang JS, Kim JM, et al. Non-tuberculous mycobacterial infection of the musculoskeletal system: pattern of infection and efficacy of combined surgical/ antimicrobial treatment. Bone Joint J. 2014;96-B:1561-5. http://dx.doi.org/10.1302/0301-620X.96B11.33427

28. Johnson MG, Stout JE. Twenty-eight cases of Mycobacterium marinum infection: retrospective case series and literature review. Infection. 2015;43:655-62. http://dx.doi.org/10.1007/ s15010-015-0776-8

29. Gundavda MK, Patil HG, Agashe VM, Soman R, Rodriques C, Deshpande RB. Nontuberculous mycobacterial infection of the musculoskeletal system in immunocompetent hosts. Indian J Orthop. 2017;51:205-12. http://dx.doi.org/10.4103/ 0019-5413.201718

30. Johnson MM, Odell JA. Nontuberculous mycobacterial pulmonary infections. J Thorac Dis. 2014;6:210-20.

Address for correspondence: Bennie Lindeque, University of Colorado, 12631 E 17th Ave, Academic Office 1, Rm 4602, Mailstop B202, Aurora, CO 80045, USA; email: bennie.lindeque@ucdenver.edu 